\title{
Molecular Evidence of Cacao swollen shoot virus Acquisition and Retention by Planococcus citri (Risso) and Pseudococcus longispinus (Targioni-Tozzetti) and Pseudococcus viburni (Signoret) Mealybugs (Hemiptera: Pseudococcidae)
}

\author{
Ekemini Obok $^{1}$, Andy Wetten ${ }^{1}$ and Joël Allainguillaume ${ }^{2}$ \\ ${ }^{1}$ School of Agriculture, Policy and Development, University of Reading, RG6 6AR Reading, United Kingdom. †Corresponding author (current \\ address): Department of Crop Science, Faculty of Agriculture, Forestry and Wildlife Resources Management, University of Calabar, Calabar, \\ Nigeria. Email: e.e.obok@unical.edu.ng; Tel.: +234-813-330-4788. 2University of the West of England, Frenchay Campus, Coldharbour Lane, \\ Bristol, BS16 1QY, United Kingdom \\ DOI: 10.29322/IJSRP.8.3.2018.p7507 \\ http://dx.doi.org/10.29322/IJSRP.8.3.2018.p7507
}

\begin{abstract}
Cacao swollen shoot virus (CSSV) remains a significant viral pathogen endemic in West African cacao-growing countries. Eradication of affected trees (complete removal) and resistance breeding in existing cacao (Theobroma cacao L.) germplasm have not yielded the expected results in terms of controlling the spread of CSSV. CSSV is reported to be vectored by at least 16 species of mealybugs (Hemiptera: Pseudococcidae), but there have been no molecular evidences to validate these reports. Inconsistent reports exit on CSSV transmission which were based on visual assessments of CSSV infection which are highly subjective, especially on asymptomatic cacao. The validation of the transmission efficiency of CSSV by mealybugs are arguable. In this study, the presence of CSSV in three mealybug species, Planococcus citri (Risso), Pseudococcus longispinus (Targioni Tozzetti) and Pseudococcus viburni (Signoret), was monitored via PCR after a 72-h virus acquisition access period (AAP) on symptomatic T. cacao (var. Amelonado) seedlings 'infected' with New Juaben, a severe strain of CSSV. Solanum tuberosum sprouts were then fed to the mealybugs over a sixday period. Sequenced PCR products of the destructively sampled and CSSV-screened individual mealybug species provided a molecular evidence of CSSV acquisition. qPCR results gave another evidence that CSSV retention is highly variable between and within mealybug species. This is the first molecular evidence highlighting a non-West African mealybug species, Ps. viburni, as a capable CSSV vector. Apparently, these results could validate the efficacy of non-malvaceous species as barrier crops and in screening for resistance to CSSV vectors in T. cacao.
\end{abstract}

Index Terms- Cacao swollen shoot virus, cacao mealybugs, Pseudococcus viburni, Amelonado

\section{INTRODUCTION}

$\mathrm{M}$ ealybugs (Pseudococcidae: Hemiptera) are natural vectors of the Cacao swollen shoot virus (CSSV) in cacao (Theobroma cacao L.) (1-3). Mechanical transmission of CSSV in cacao is possible by grafting and budding with great difficulty (4-10). Field observations for CSSV infection in cacao are subjective; prone to misdiagnosis e.g. plant nutrient deficiencies (12). The relative efficiency of CSSV acquisition and infection rates of vector mealybugs have solely been determined by the number of symptomatic plants (13). Such reports may also have been underestimating transmission events due to failures to detect latent CSSV infections in cacao. The only well documented evidence of mealybug-virus-plant relationship Roivainen (14) had no molecular-based evidence to substantiate the results from earlier studies $(15,16)$. Roivainen $(17)$ reported that first instar nymphs of Formicococcus njalensis were still capable of transmitting CSSV, an assumed non-persistent stylet-borne plant virus, after ecdysis. Results from Roivainen's findings lacked molecular validation to ascertain the integrity and persistence of CSSV in the source plants, 'viruliferous' moulted mealybug, the exuviae and unmoulted mealybugs. In an attempt to understand the mealybug-CSSV-cacao interactions, the feeding activities of the vector mealybugs before CSSV acquisition (preliminary feeding or starvation), during (acquisition access period i.e. AAP) and after CSSV acquisition (inoculation access period i.e. IAP) (18) have significant roles to play in defining these interactions (Figure 4.1). Strickland (19) presented the first detailed account of mealybug species occurring on cacao in West Africa. The initial search for the vectors of CSSV led to the identification of two mealybug species, Fo. njalensis Laing and Fe. virgata Ckll., an aphid (Toxoptera coffeae Nietner) and a psyllid (Mesohomotoma tessmanii Aulm) as vectors of CSSV 1A strain (9). In a subsequent confirmation study, Pl. citri was first pointed out by Box (2) to transmit the CSSV 1C and 1D strains (20) of which Posnette (21) further confirmed the status of $\mathrm{Pl}$. citri as a known vector of CSSV after the successful transmission of additional CSSV strains. 
Inconsistent results (2) showed that none of the non-mealybug vectors were capable of transmitting CSSV in subsequently repeated studies. Pl. citri is a highly polyphagous mealybug species; with conflicting reports on its origin as reviewed by Franco, Suma (22), it has a wider global distribution (23). Previous studies have shown that Ps. longispinus, native to Australia (22), was not among the dominant mealybug species found on cacao (19, 24-27). However, Ps. longispinus was enlisted as a vector mealybug species of CSSV following an extensive CSSV transmission study by Posnette (28) involving 17 groups ('strains') of Theobroma virus I (i.e. CSSV) from Ghana (8), Nigeria (7) and Cote d'Ivoire (2); this study used 10 species of mealybugs in addition to the already mentioned three species, Fo. njalensis, Fe. virgata and Pl. citri. The third mealybug species used in the present study is Ps. viburni. Though it is not native to the afrotropical cacao-growing areas of West Africa (29), it is a polyphagous Nearctic (22, 30) species which has been reported on grapevine in South Africa (31, 32). Ps. viburni has not been found on cacao anywhere, neither has it been used in any demonstration study as a vector of CSSV. This study aimed at providing findings on molecular-based evidence relating to CSSV acquisition and retention within three mealybug species, two previously classified as 'CSSV-vectors' (Pl. citri and Ps. longispinus) and a 'non-CSSV vector' Ps. viburni, using PCR and qPCR analyses. The objectives of the study were to establish (1) the capacity (if any) for acquisition of CSSV by these species, fed on CSSV-infected cacao and (2) the retention time of CSSV in the viruliferous mealybug species fed on a non-malvaceous non-CSSV host species (S. tuberosum).

\section{MATERIALS AND METHODS}

\section{A. CSSV-infected and CSSV-free cacao plants}

Whole plants and/or leaves of young (3 - 4 months old) CSSV-infected and CSSV-free cacao seedlings (var. Amelonado) were used as source and test plants, respectively. These CSSV-infected plants were raised from CSSV-infected seeds obtained from the Cacao Research Institute, Ghana (CRIG) These were sown in compost (75\%) - vermiculite (25\%) mix in lightweight standard seed trays $(34.4 \mathrm{~cm} \times 21.4 \mathrm{~cm} \times 5.2 \mathrm{~cm}$ ) (Fig. 1A). The growing medium was adequately wetted and maintained inside seedbed tunnels (25 $\left.\pm 2{ }^{\circ} \mathrm{C}, 60-65 \% \mathrm{RH}\right)$ with automated watering and heating systems. Two weeks after germination, successfully emerged individual seedlings were carefully transplanted into plastic pots $(14 \mathrm{~cm} \mathrm{x} 12 \mathrm{~cm})$ (Fig. 1B). Water-based fertilizer supplement, Sangral 3:1:1 (William Sinclair Holdings Plc, Lincoln, UK) were supplied at intervals of four weeks. The CSSV-free cacao seedlings were obtained from the International Cacao Quarantine Centre, Reading (ICQC).

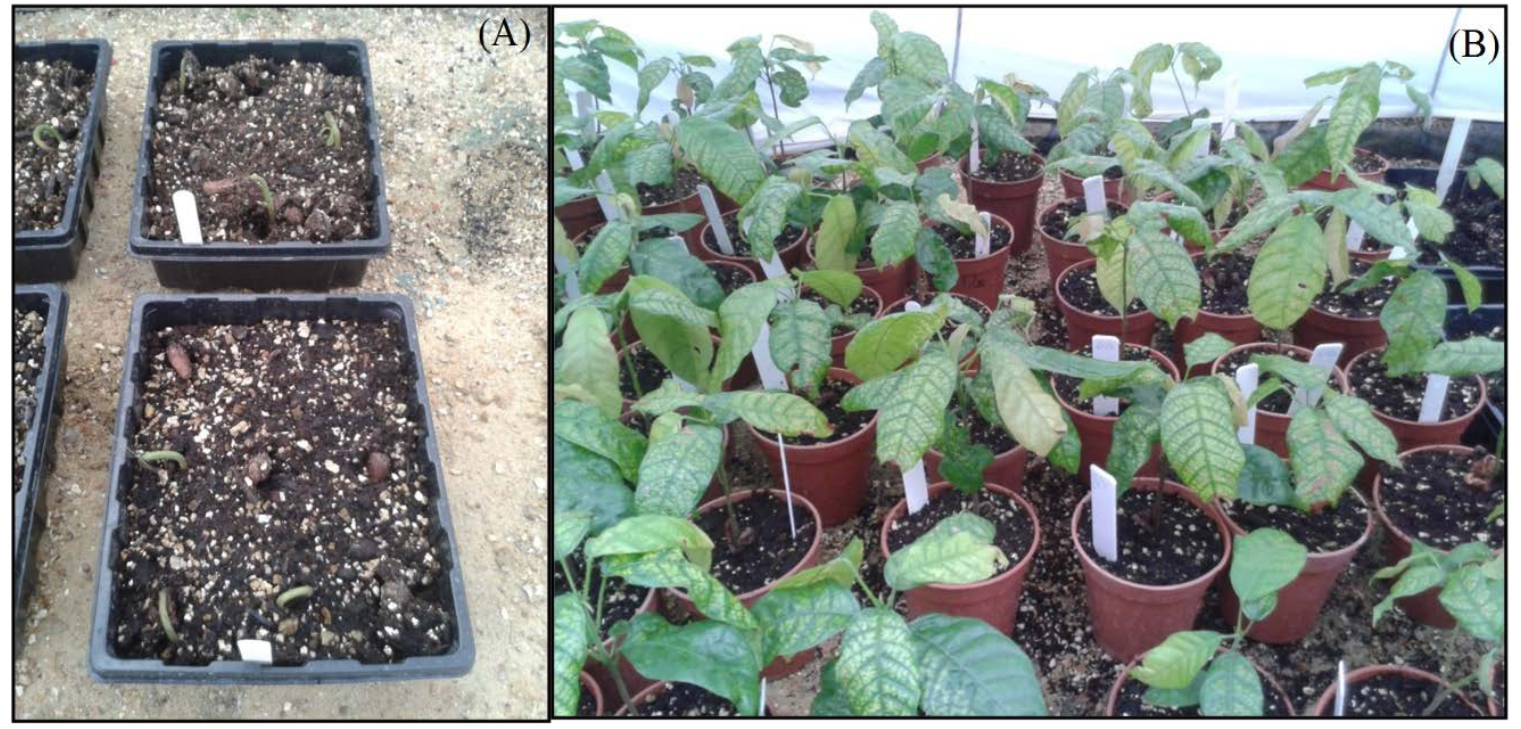

Figure 1: CSSV inoculated cacao seeds at (A) 7 and (B) 30 days after sowing in individual plastic pots.

\section{B. Mealybugs culture}

Two mealybug species often found in West African cacao, Pl. citri and Ps. longispinus, were used for the study. The mealybug species, Ps. viburni, which has not been reported on cacao in the field, was included as a control for comparative purposes. Clean potato (Solanum tuberosum L.) tubers (average size, $6 \mathrm{~cm} \mathrm{x} 4 \mathrm{~cm}$ ) were purchased from the local grocery in Reading, UK. Potato tubers with $\geq 3$ nodes ('eyes') were selected and kept in dark conditions to induce sprouting. After sprouting the potato tubers for 1-2 weeks, about 3-5 tubers were placed in a plastic lunch box $(30 \mathrm{~cm}$ x $10 \mathrm{~cm} \times 10 \mathrm{~cm})$. The boxes were lined on the inside with paper towels. The lid was cut open $(7 \mathrm{~cm} \times 5 \mathrm{~cm})$ in the middle and sealed with a breathable paper to ensure adequate ventilation. Colonies of female mealybugs and groups of egg sacs previously collected were then placed directly on each of the sprouts for mass rearing. The mealybug cultures in each box were retained in screen cages $(40 \mathrm{~cm} \times 40 \mathrm{~cm} \times 70 \mathrm{~cm}$ ) inside growth chambers (Sanyo 600G3/TTL, Sanyo Gallenkamp Plc, Loughborough, UK) at $25 \pm 2^{\circ} \mathrm{C}, 50-55 \%$ RH, 14:10 - L:D. Second instar (females) (Fig. 2A) of these three mealybug species were all obtained from cultures maintained in the mealybug husbandry. 

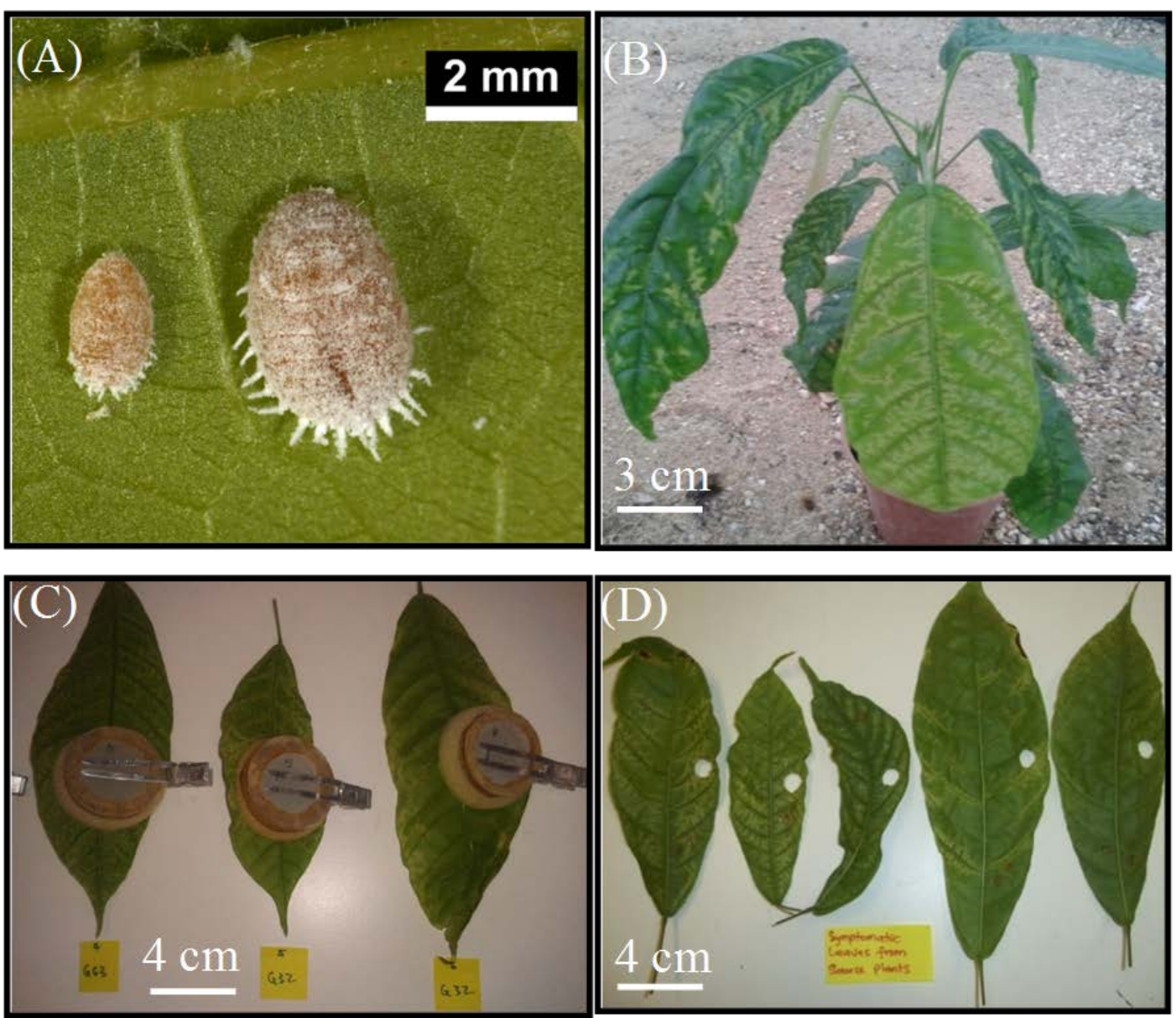

\section{Figure 2: Mealybugs and CSSV acquisition feeding: (A) $2^{\text {nd }}$ instar (left) and adult female (right) of $\mathrm{Pl}$. citri mealybug on cacao leaf (background) (B) CSSV infected cacao seedling (C) trap-and-clip system (D) disc sampled symptomatic leaf.}

C. CSSV acquisition by mealybugs species fed on CSSV-infected cacao plants

Groups of newly moulted $2^{\text {nd }}$ instar CSSV-free female mealybugs were first collected and starved for $24 \mathrm{~h}$. These were loaded into a trap cage made up of an open-end transparent Perspex (acrylic) glass cylinder ( $\mathrm{h}=0.7 \mathrm{~cm}, \varnothing=3 \mathrm{~cm}$ ). One end of the cylinder was completely sealed off with a fine mesh $(0.025 \mathrm{~mm})$ which served as a platform for loading the mealybugs into the trap with 10 mealybugs in each trap. The open end of each mealybug-loaded trap was gently positioned placed over the abaxial side of a CSSVinfected cacao seedling, held in position with lightweight aluminium spring clips. The trap was tapped gently on the mesh fitted end, to dislodge the mealybugs onto the cacao leaf surface. The entire experimental setup, in four replications for the three species, was maintained in screen cages inside the growth chamber (Fig. 3). The entrapped mealybugs were allowed in this feeding position on CSSV-infected cacao seedlings for $72 \mathrm{~h}$. The traps were then removed, individual mealybugs were separately collected for DNA extraction and subsequent PCR screening for evidence of CSSV. 

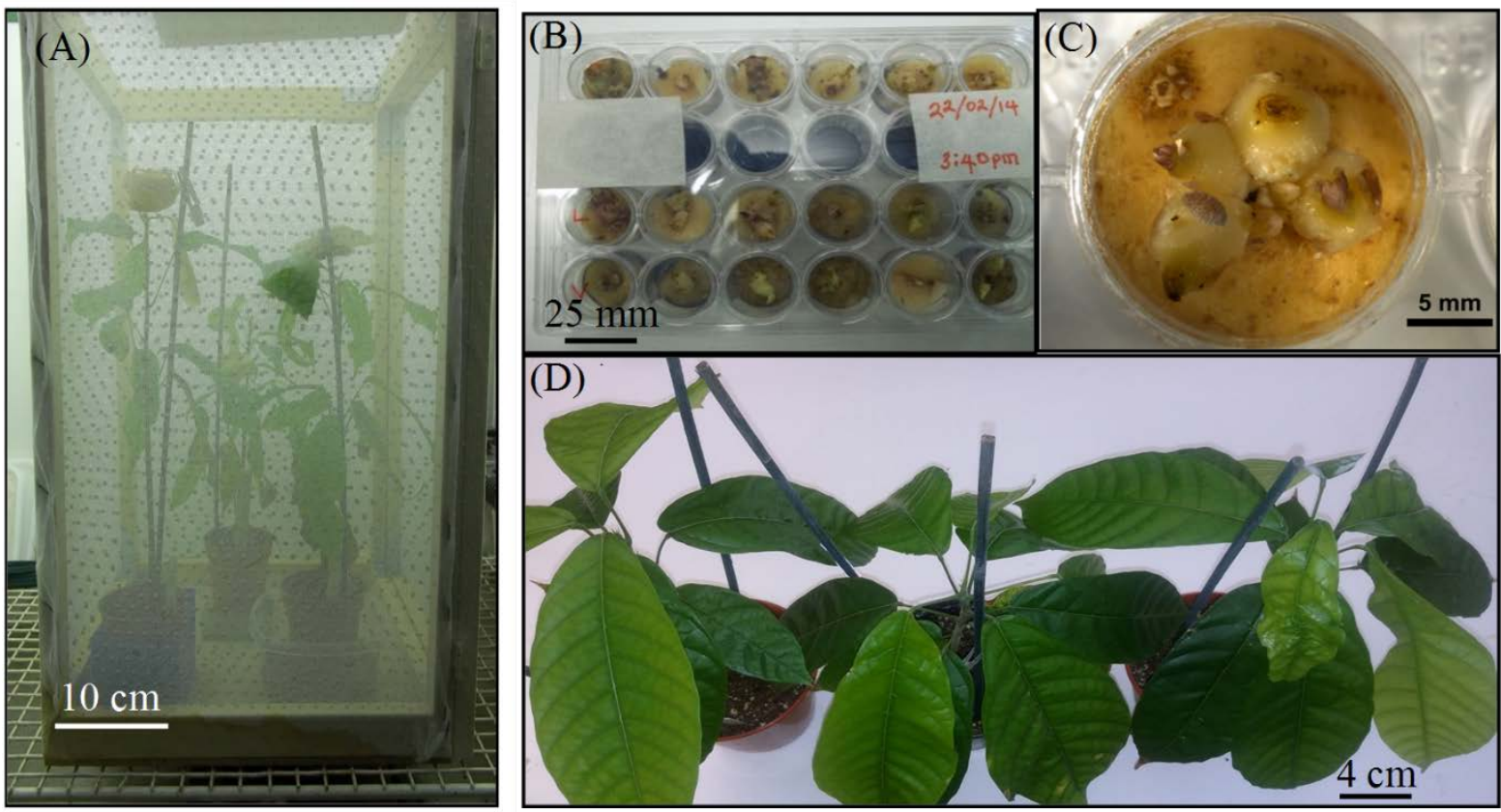

Figure 3: (A) Screen cage with in situ CSSV infected seedling carrying mealybugs in clip cages, (B and C) viruliferous mealybugs on cacao-free diet (Solanum tuberosum sprouts) and (D) CSSV-free cacao (var. Amelonado) seedlings (test plants).

\section{CSSV retention by viruliferous mealybugs fed on potato}

Groups of newly moulted $2^{\text {nd }}$ instar mealybugs were collected, starved for $24 \mathrm{~h}$ then given a 72-h virus Acquisition Access Period (AAP) on cacao seedlings (var. Amelonado) infected with the New Juaben strain of CSSV. The 'viruliferous' mealybug individuals were then transferred to S. tuberosum sprouts (a non-CSSV host) (Fig. 3). Thereafter, at daily intervals over a six-day period, individuals were destructively sampled and PCR-screened for CSSV presence prior to qPCR analysis.

E. PCR and qPCR analyses of mealybugs exposed to CSSV-infected cacao

Mealybug DNA samples were first screened with conventional qualitative PCR using primers designed to produce a 500 bp fragment upon detection of a DNA sequence from Open Reading Frame 1 (ORF1) of CSSV isolate 'New Juaben'. The qPCR analyses were performed using the following primer pair: forward (CSSVORF1Sf): 5'-ACC AAG CAG TTC CGA GAA AAC-3' and reverse (CSSVORF1Sr): 5'-GGC TCA TTG ACC ACC CAT TG-3'. These primers were designed within this sequence to yield a $130 \mathrm{bp}$ fragment, a size optimised for real-time PCR (qPCR) which was performed on the same mealybug DNA extractions using SensiMix ${ }^{\mathrm{TM}}$ SYBR $^{\circledR}$ and Fluorescein kits (Bioline) on a QIAGEN Rotor-Gene 6000 thermocycler. Each $25 \mu \mathrm{l}$ qPCR reaction consisted of SensiMix $^{\mathrm{TM}}(12.5 \mu \mathrm{l})$, ORF1 forward and reverse primers $(2 \mathrm{mM}, 2.5 \mu \mathrm{l}), \mathrm{ddH}_{2} \mathrm{O}(5 \mu \mathrm{l})$ and DNA $(5 \mu \mathrm{l})$. Master mix solutions comprising SensiMix ${ }^{\mathrm{TM}}$, primers and water were prepared in excess for the $72 \times 25 \mu \mathrm{l}$ reactions that were conducted for each run of the Rotor-Gene. Mealybug DNA samples were run in duplicate and each run also included a dilution series of the source plant (CSSVinfected) DNA diluted at $10^{-1}, 10^{-2}$ and $10^{-3}$ (each in duplicate).

\section{RESULTS}

A. Detection and quantification of CSSV in mealybugs by PCR and qPCR

Primers for the qualitative PCR were designed in the conserved regions of the six published sequences of the CSSV genome, National Centre for Biotechnology Information (NCBI) accession number AJ608931 (11, 33) (Fig. 4A). Fig. 4B shows the gel electrophoretic image of the expected product size for CSSV positive and negative control samples. A portion of the 180 bp fragment sequence used for the qPCR is shown in Figure 5. 


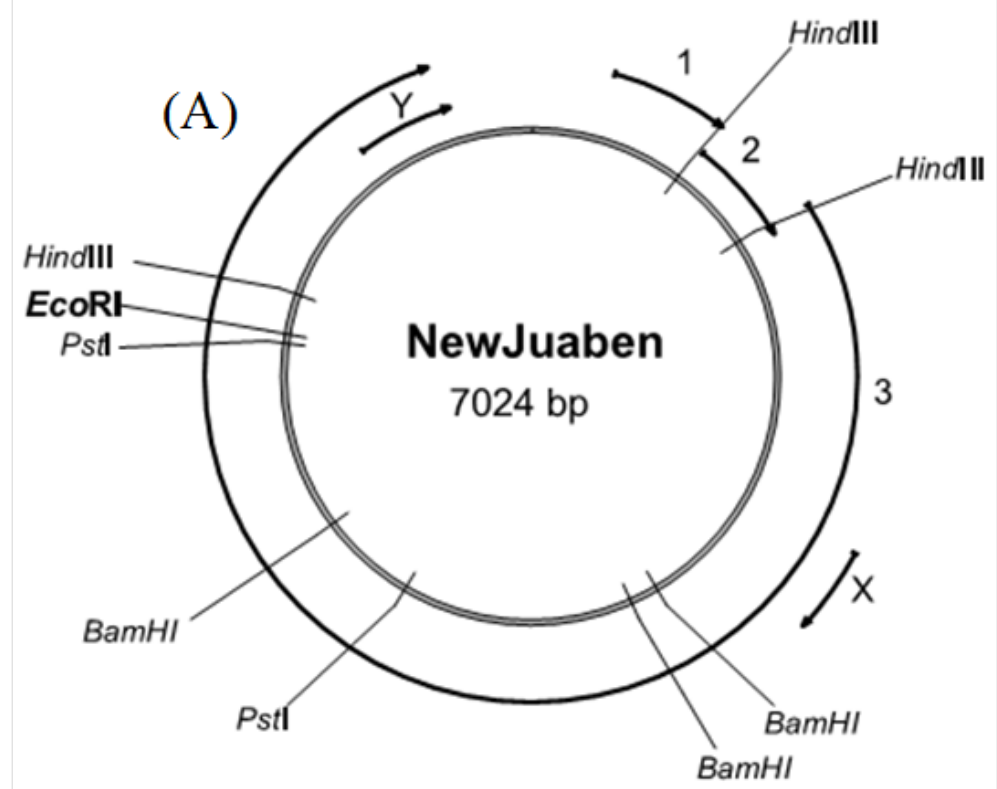

Ladder Positive sample Negative control

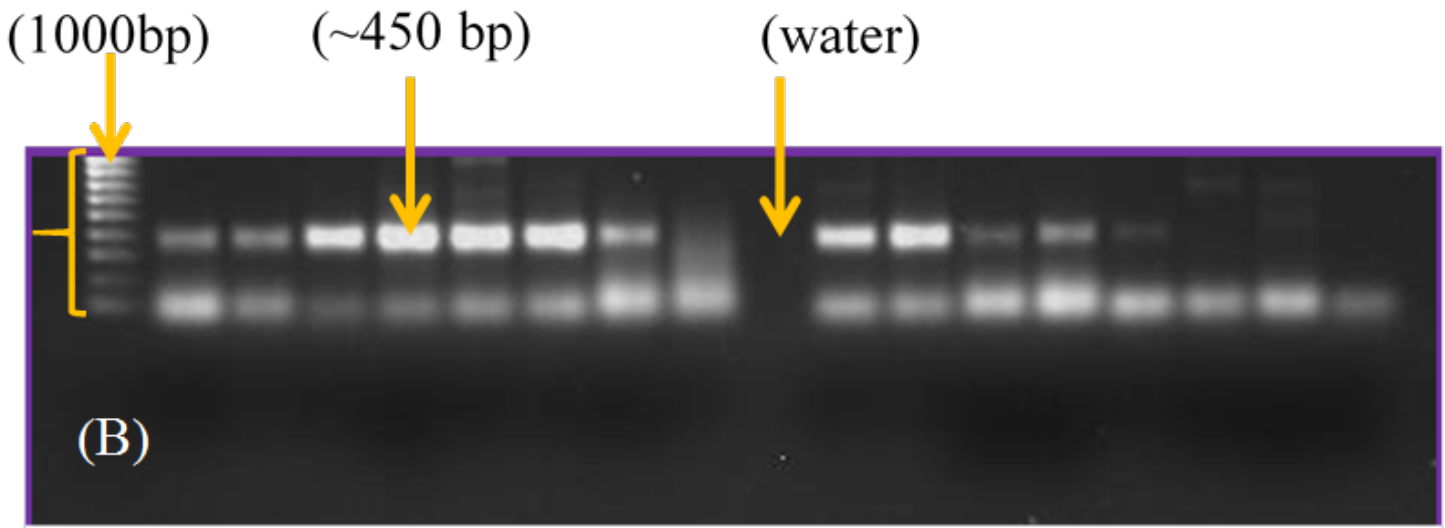

Figure 4: (A) The genome of the New Juaben isolate (11) utilised in the present study, showing sites of the restriction endonucleases, BamHI, EcoRI, HindIII, PstI and the five open reading frames (ORFs) 1, 2, 3, X and $\mathrm{Y}$. (B) An agarose electrophoretic gel image showing expected product size for OR1 primer against CSSV-positive samples and control (DNA template-free) sample. 


\section{A added by PCR at the end of the product}

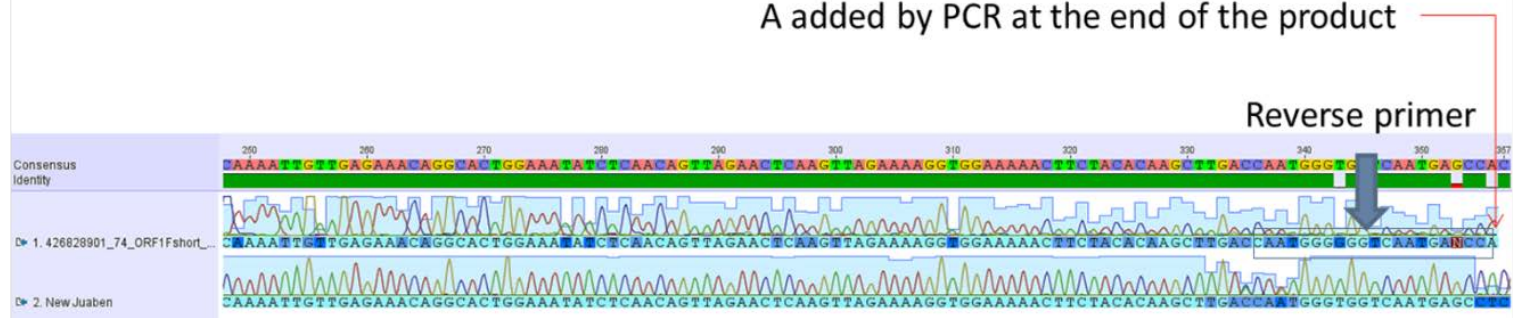

Figure 5: Portion of read from Sanger sequencing of $180 \mathrm{bp}$ fragment produced with 'CSSVORF1Sf and CSSVORF1Sr primers with Planococcus citri sample 74 (144 h post-AAP on cacao-free diet) showing $100 \%$ homology with published sequence for the New Juaben strain of CSSV (NCBI accession number AJ608931).

\section{B. Evidence of CSSV acquisition and retention by mealybugs}

It was demonstrated that Ps. viburni can acquire and retain CSSV in a similar manner to Pl. citri and Ps. longispinus (Fig. 6). The potential infectivity status of viruliferous mealybugs for all the three species was apparently not lost after feeding on the non-cacao diet as shown by the ORF1 PCR and qPCR screening results. Individuals of all three mealybug species showed evidence of CSSV retention after transfer to a potato tuber diet (in which the virus will not proliferate) (Fig. 6). PCR products (comparable with the positive controls from the CSSV-positive donor cacao) generated from mealybug extractions, when purified and submitted for DNA sequencing (conducted by SourceBioscience, Oxford) were 100\% matches with that of the CSSV isolate 'New Juaben'. Products of a non-target size (e.g. sample 6 in Figure 6 which can be seen to be below the 300 bp size maker) did not produce sequences that matched any badnavirus DNA sequences. Real time PCR analysis of the same samples began with a dilution series of the source CSSV-positive cacao leaf (Fig. 7A). The quantitative analysis worked as expected with duplicated samples amplifying at approximately the same position and the increasingly dilute CSSV samples $\left(10^{-2}\right.$ and then $\left.10^{-3}\right)$ not amplifying until after further cycles of PCR amplification (Fig. 7A). Products from mealybug samples were most frequently generated at levels that fell between those of the $10^{-2}$ and $10^{-3}$ dilutions of the source leaf DNA values (Fig. 7B). The qPCR primers were used to generate products from these mealybug samples for sequencing using conventional PCR (because real time PCR products are not directly available for sequencing) and when the resultant sequences of the 130 bp products were assessed they were $100 \%$ matches with that of the CSSV isolate 'New Juaben'. Melt analysis of the real-time PCR products was conducted and only those that showed a melt temperature that did not diverge significantly from that of the CSSV-positive control $\left(c a .80^{\circ} \mathrm{C}\right)$ were recorded as positive. There was consistency between the two methods of sample analysis with, for example, sample 74 (a Pl. citri individual fed on potato for $144 \mathrm{~h}$ ) producing the particularly intense band on agarose following conventional PCR (Fig. 6) and also generating the highest real time PCR signal of all the 84 mealybug samples analyzed (Fig. 7C). However, the greater sensitivity of the real-time PCR analysis meant that for each species time point the number of mealybug samples positive for the presence of CSSV DNA was equivalent to or greater than that shown by conventional PCR with all three species exhibiting viral retention six days after leaving their CSSV-infected food supply (Table 1).

Table 1: Retention of CSSV in three mealybug species fed on CSSV+ cacao for $72 \mathrm{~h}$ followed by transfer to a potato diet for 0 to 144 $h$, as detected by conventional and real-time PCR (data in parentheses). $n=4$

\begin{tabular}{llllllll}
\hline \multicolumn{7}{l}{ Duration on potato diet after transfer from CSSV source plant (h) } \\
\cline { 2 - 7 } Mealybug species & $\mathbf{0}$ & $\mathbf{2 4}$ & $\mathbf{4 8}$ & $\mathbf{7 2}$ & $\mathbf{9 6}$ & $\mathbf{1 2 0}$ & $\mathbf{1 4 4}$ \\
\hline Planococcus citri & $1 / 4(3 / 4)$ & $2 / 4(2 / 4)$ & $2 / 4(4 / 4)$ & $2 / 4(2 / 4)$ & $1 / 4(3 / 4)$ & $1 / 4(3 / 4)$ & $1 / 4(3 / 4)$ \\
& & & & & & & \\
Pseudococcus & $1 / 4(2 / 4)$ & $3 / 4(4 / 4)$ & $-/ 4(2 / 4)$ & $1 / 4(4 / 4)$ & $1 / 4(4 / 4)$ & $1 / 4(2 / 4)$ & $-/ 4(2 / 4)$ \\
$\begin{array}{l}\text { longispinus } \\
\text { Pseudococcus viburni }\end{array}$ & $1 / 4(3 / 4)$ & $1 / 4(3 / 4)$ & $2 / 4(3 / 4)$ & $1 / 4(3 / 4)$ & $-/ 4(3 / 4)$ & $1 / 4(1 / 4)$ & $1 / 4(1 / 4)$ \\
\hline
\end{tabular}

'-' = PCR negative 


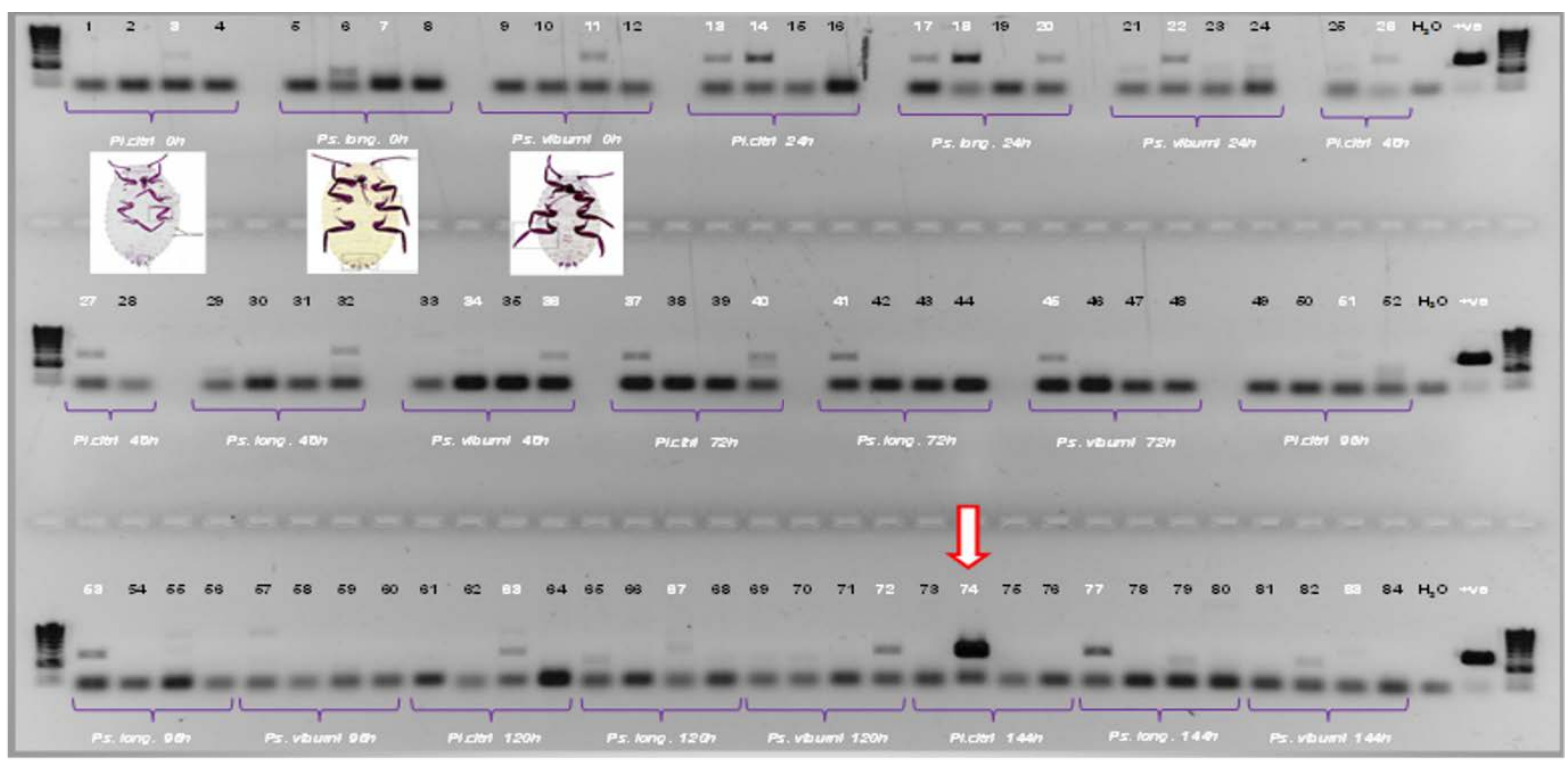

Figure 6: Retention of CSSV by 3 mealybug species fed on virus-infected cacao, then transferred to CSSV-free diet for 0 to 6 days as determined by qualitative PCR (white numbers $=\mathrm{CSSV}+$ mealybugs). Arrow highlights particularly strong product from $144 \mathrm{~h}$ Planococcus citri individual (sample 74).
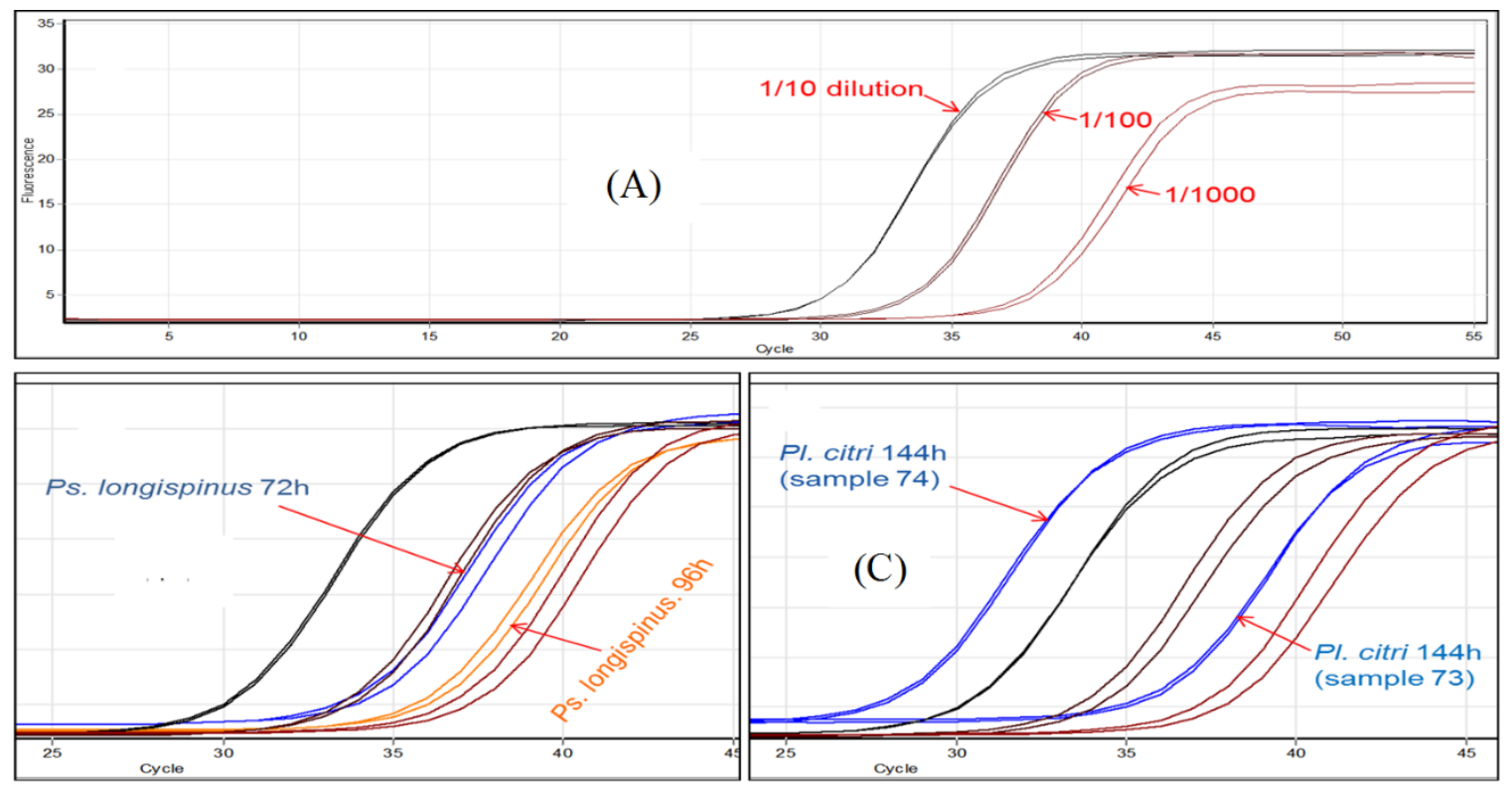

Figure 7: Retention of CSSV by mealybugs as determined by real time PCR. (A) Each run of up to 72 reactions included duplicated reference samples from the CSSV infected source leaf dilutions $10^{-1}, 10^{-2}$ and $10^{-3}$. (B) CSSV levels in these $72 \mathrm{~h}$ and $96 \mathrm{~h}$ Pseudococcus longispinus samples were between those of the $10^{-2}$ and $10^{-3}$ leaf dilutions. (C) Sample 74 showed the highest CSSV concentration and samples such as 73 (apparently, virus-free according to the qualitative PCR) showed detectable CSSV via real-time analysis.

\section{Screening of cDNA from CSSV-infected cacao}

Total genomic DNA and cDNA from leaf samples of CSSV infected seedlings we screened against four CSSV specific primers: ORF1, MP, RNase and RTase (Fig. 8). The result demonstrated that the approach for detecting CSSV presence from the DNA extracted from an infected cacao leaf could work as well with cDNA synthesis from RNA extracted from the exact same CSSVinfected cacao leaf. 


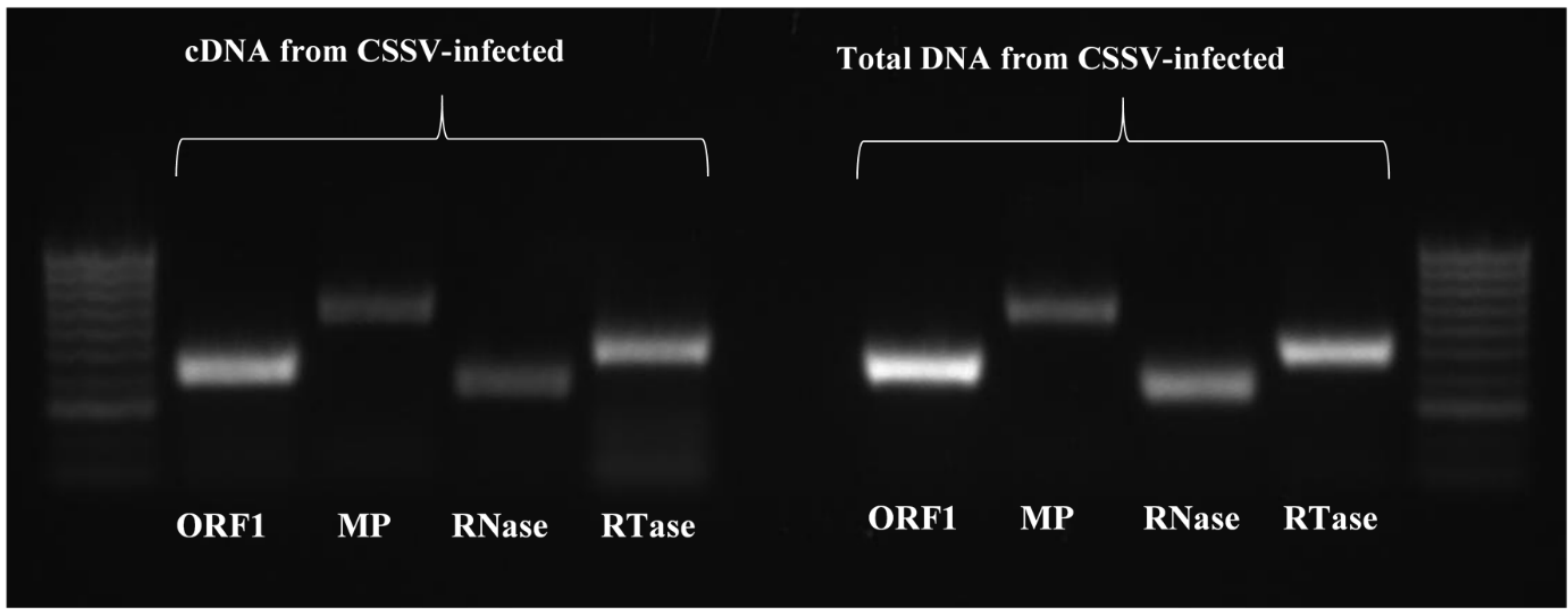

\section{Figure 8: Comparison of CSSV-screened PCR products from total genomic DNA and cDNA of CSSV-infected cacao seedling.}

\section{DISCUSSION}

The effectiveness of mealybugs as virus vectors is said to be species dependent and varies according to their favoured feeding sites on the cacao plant and with respect to the age of the plant (14) and the determinants of the mode of virus transmission and infection by vectors are retention time, site of retention and internalization of viral particles (virions) by vectors (Andret-Link and Fuchs, 2005). In non-circulative stylet-borne viruses, the virions are dislodged during a sustained feeding duration and it is presumed that on subsequent ingestion, these virions are not reacquired by previously occupied positions on the stylets once they have been released (34). Differences in cacao infection rates, for example, have been observed between the mealybug vectors Formicococcus njalensis and Ferrisia virgata with distinct stylet dimensions and frequency of phloem penetration being proposed as the cause (35). In previous studies, Fo. njalensis and Pl. citri were considered to be the most important viral vectors on cacao as, at the time, they were generally the predominant mealybugs on the crop in the Afrotropical region $(19,24,27,36,37)$ respectively. Persistence of the virus within the vectors is reported to differ between the two species with Fo. njalensis showing a gradual decline in infectivity up to $18 \mathrm{~h}$ post acquisition feeding while $\mathrm{Pl}$. citri transmission rates over a similar period were constant (13). However, of these two species, while Pl. citri is usually present in lower numbers in West Africa (38), its greater mobility and ability to infest new cacao trees make it potentially the more important virus vector. Reports have indicated that, in keeping with its classification as a semi-persistent virus, CSSV is retained by its mealybug vectors for only a matter of hours or days after feeding on an infected source plant ceases. Roivainen (17) (reviewed by Roivainen (14)) recorded the longest period of CSSV retention to date when he reported that infectivity persisted in starved nymphs of Fo. njalensis until $72 \mathrm{~h}$ after virus acquisition. The present study demonstrated that all three mealybug species under test were capable of retaining viral DNA until at least $144 \mathrm{~h}$ after virus acquisition and that was in a scenario more analogous to a cacao plantation-border crop i.e. with mealybugs continuing to feed on a non-malvaceous crop. The current work also demonstrated that conventional qualitative PCR can be used to detect CSSV DNA in mealybugs that have fed on virus infected cacao. This approach also indicated that for two of the three test species when mealybugs were switched from CSSV-positive cacao hosts to a potato tuber diet it was still be possible to detect CSSV DNA in their bodies six days later. When qPCR was applied to the same samples the superior sensitivity of that screening approach revealed that many of the apparently virus-free mealybugs still contained detectable levels of CSSV DNA. This suggests that the majority of viruliferous juvenile mealybugs retain at least some of their viral load until they next undergo ecdysis (skin shedding) when they lose the lining of the foregut where the virus is thought to be retained. However, it has been established in the present study that Ps. viburni has the potential of acting as a vector of CSSV between cacao plants as shown by its ability to acquire and retain the virus. Interestingly it was reported that Ps. viburni and Ps. longispinus have a similar 16S rRNA sequence of the same primary endosymbiont, 'Candidatus Tremblaya princeps' (39), a $\beta$-proteobacterium present in Pl. citri (40-42). These three species also act as vectors of Grapevine leafroll-associated virus $3(39,43)$ and this could partly explain why Ps. viburni, not native to the cacao producing areas of West Africa, is also able to acquire and retain CSSV. The information obtained in the present study on the acquisition and retention of CSSV by mealybugs previously implicated as vectors has now been validated with molecular evidence. This will be useful in planning future transmission studies targeted at other mealybug species with the aim of testing their 'potential' infectivity. Although Ps. viburni is not present in the main West African cacao growing countries, its presence in areas relatively close to the cacao growing belts, in Africa (Morocco, Saint Helena, South Africa and Zimbabwe), South America (Brazil, Costa Rica, Guatemala, Jamaica, Mexico, Panama, Peru, Venezuela) and Asia (Indonesia, Philippines, Sri Lanka) (44) and its demonstrated ability to acquire and retain CSSV could jointly have implications for its emergence as an invasive pest on cacao of which its ecological adaptation could be driven by climate change towards the cacao-growing areas. 
The influence of climate change on mealybug distribution has been reported on 'potential' invasive species including the pink hibiscus mealybug, Maconellicoccus hirsutus (Green) in Chile (45), the cassava mealybug, Ph. manihoti Matile-Ferrero in Asia (46) and the cotton mealybug, Ph. solenopsis Tinsley (47) in India. Given that the capacity to control climate change effects on agroecology is limited, it may be appropriate to consider measures and management options for Ps. viburni invasion in the future, possibly including eradication, containment and integrated pest management strategies. Together with the results from the present work that indicate long viral retention times for Ps. viburni and the two known vectors these findings suggest efforts to locally eliminate individual mealybug species (e.g. through the use of a sterile male release approach) may be undermined by the possible subsequent occupation of niches by sympatric mealybug species and/or immigration of species from further afield. The use of predators and parasitoids in the control of mealybugs, for example Pl. citri, has met with minimal success partly due to the fact that its origin remains unknown $(22,48)$ and there is the difficulty to acclimatize its natural enemies (predators and parasitoids) under different temperature requirements to match the mealybug population on susceptible host plant (49). In addition to the expense associated with the rearing and release of mealybugs predators and parasitoids, it was also reported by Mendel, Gross (49) that the augmentation of the release of mealybug parasitoids could not bring about the expected result of reducing the population of Pl. citri on Citrus spp on the field. With their hydrophobic wax coating (50), defending attendant ant species (51) and herbivory of a crop the fruit of which must be protected from chemical tainting, mealybug CSSV vectors present a challenging target for control by insecticide application. With the use of the most widely employed chemical control (Imidacloprid) becoming increasingly restricted, precise information about the effectiveness of new alternative pesticides becomes a priority. The application of electrical penetration graph (EPG) technique to study insecticide impact on mealybug feeding could be a useful approach to embrace. EPG monitoring of feeding hemipterans provides the most sensitive means of determining the effectiveness of candidate insecticides and can support the more targeted, environmentally sensitive, and economical use of such chemicals. By time course EPG analysis of mealybugs feeding on cacao treated with, for example, soil drench insecticide applications, threshold control concentrations may be accurately determined; this may reduce the occurrence of insecticide resistance which has been reported in mealybugs, for example Pl. citri (49).

\section{CONCLUSION}

Further studies are required to build knowledge on the 'new' mealybug vector and mechanism of CSSV infection. Since it has now been demonstrated in the present study that CSSV can be detected in both total genomic DNA and cDNA synthesised from RNA extracted from CSSV-infected cacao plant, it will then be suitable to use this approach straight away on testing cacao plants (CSSVfree) after CSSV inoculation by viruliferous mealybugs. Subsequently, this could be useful for CSSV screening purposes in breeding for resistance to CSSV and vector mealybugs on different cacao genotypes. Another suggestion will be the use of EPG to monitor and characterise mealybugs feeding on different genotypes of cacao, and the time taken to achieve infection. In addition, the outcome of the combined EPG and systemic pesticide application study on cacao would inform parallel field experiments being set up in West African cacao-growing countries.

\section{ACKNOWLEDGMENTS}

I thank Dr George Ameyaw (CRIG, Tafo-Akim) for the supply of mealybug-inoculated CSSV-infected cacao seeds. This work was a part of the author's PhD study which was primarily sponsored by the Commonwealth Scholarship Commission, UK [award number NGCS-2012-337].

\section{REFERENCES}

[1] Posnette AF. Swollen-shoot virus disease of cacao. Trop. Agr. 1941; 18(5): 87-90.

[2] Box HE. Insect transmission of the 'swollen-shoot' virus in West African cacao. Nature. 1945; 155(3942): 608-609.

[3] Cotterell GS. Entomology section. Report Central Cacao Research Station Tafo 1938-1942. 1943: 51-4.

[4] Brunt AA, Kenten RH. Mechanical transmission of cacao swollen-shoot virus. Virology. 1960; 12(2): 328-330.

[5] Brunt AA, Kenten RH. Mechanical transmission of cacao swollen-shoot virus to and from cacao and other hosts. Ann. Appl. Biol. 1962; 50(4): 749-754.

[6] Wessel-Riemens PC. The use of proteins and alkaloids in mechanical transmission of Nigerian isolates of cacao swollen-shoot virus. Virology. 1965; 27(4): 566570 .

[7] Adomako D, Owusu GK. Studies on the mechanical transmission of cacao swollen shoot virus: Some factors affecting virus multiplication and symptom development in cacao. Gh. J. Agr. Sci. 1974; 7: 7-15.

[8] Posnette AF. Transmission of "swollen shoot" disease of cacao. Trop. Agr. 1940; 17(5): 98.

[9] Posnette AF, Strickland AH. Virus diseases of cacao in West Africa: III. Technique of insect transmission. Ann. Appl. Biol. 1948 ; 35(1): 53-63.

[10] Glendinning DR, Legg JT, Lovi NK, Martinson VA. A field experiment in Ghana on the tolerance of cacao seedlings to cacao swollen-shoot and cacao mottleleaf viruses. Ann. Appl. Biol. 1966; 57(3): 389-396.

[11] Muller E, Sackey S. Molecular variability analysis of five new complete cacao swollen shoot virus genomic sequences. Arch. Virol. 2005; 150(1): 53-66. PubMed PMID: 15338327.

[12] Lockard RG, Asomaning EJA. Mineral nutrition of Cacao Theobroma cacao L.. II-Effects of swollen shoot virus on the growth and nutrient content of plants grown under nutrient deficiency, excess and control conditions in sand culture. Trop. Agr. (Trinidad). 1965; 42(1): 39-53. 
[13] Posnette AF, Robertson NF. Virus Diseases of Cacao in West Africa: VI. Vector investigations. Ann. Appl. Biol. 1950; 37(3): 363-377.

[14] Roivainen O. Mealybugs. In: Harris KF, Maramorosch K, editors. Vectors of Plant Pathogens. London: Academic Press Inc.; 1980. p. 15-38.

[15] Owusu GK, editor Availability of Cacao swollen shoot virus to mealybugs from tolerant and sensitive cacao. 3rd International Cacao Research Conference; 23-29 November 1969; Accra, Ghana.

[16] Thresh JM, Owusu GLK, Ollennu LAA. Cacao swollen shoot - an archetypal crowd disease. Z Pflanzenk Pflanzen. 1988; 95(4): 428-446. PubMed PMID: WOS:A1988Q338600012. English.

[17] Roivainen O, editor Circulative transmission of cacao swollen shoot virus by the mealybug Planococcoides njalensis (Laing) (Homoptera: Pseudococcidae). 3rd International Cacao Research Conference; 23-29 November 1969; Accra, Ghana: Cacao Research Institute Ghana.

[18] Roivainen O. Transmission of Cacao viruses by mealybugs (Homoptera: Pseudococcidae). J. Agr. Sci. Finland. 1976; 48: $203-304$.

[19] Strickland AH. Coccids attacking Cacao (Theobroma cacao L.), in West Africa, with Descriptions of five new Species. B. Entomol. Res. 1947; 38(3): 497-523.

[20] Posnette AF. Virus diseases of cacao in West Africa: cacao viruses 1A, 1B, 1C and 1D. Ann. Appl. Biol. 1947; 3(3): 388-402. PubMed PMID: 20271954.

[21] Posnette AF. Use of seeds in the insect transmission of some plant viruses. Nature. 1947; 159(4041): 500-501.

[22] Franco JC, Suma P, da Silva EB, Blumberg D, Mendel Z. Management strategies of mealybug pests of citrus in mediterranean countries. Phytoparasitica. 2004; 32(5): 507-522.

[23] CABI. Planococcus citri, Pseudococcus longispinus and Pseudococcus viburni Wallingford, UK.: CAB International; 2015 [11 September 2015$]$. Available from: http://www.plantwise.org/KnowledgeBank/Map/.

[24] Campbell CAM, editor The distribution of mealybug vectors of CSSV within trees. Proceedings of the 4th Conference of West African Cacao Entomologists; 913 December 1974; Zoology Department, University of Ghana, Legon, Ghana.

[25] Cornwell PB, editor Mealybug population, distribution and migration. West African International Cacao Research Conference; 12-16 December 1953; The West African Cacao Research Institute, Tafo, Gold Coast.

[26] Donald RG. Mealybug studies. Annual Report of the West African Cacao Research Institute 1954-55. Tafo, Ghana: West African Cacao Research Institute; 1955. p. 101-104.

[27] Campbell CAM. The assessment of mealybugs (Pseudococcidae) and other Homoptera on mature cacao trees in Ghana. B. Entomol. Res. 1983; 73(1): $137-151$.

[28] Posnette AF. Virus diseases of cacao in West Africa: VII. Virus transmission by diffrent vector species. Ann. Appl. Biol. 1950; 37(1): 127-132.

[29] Scale Insects, Edition 2 [Internet]. USDA APHIS Identification Technology Program (ITP). 2014 [cited 15 June 2014]. Available from: $<$ http://idtools.org/id/scales/>.

[30] Miller DR, Miller GL, Watson GW. Invasive species of mealybugs (Hemiptera: Pseudococcidae) and their threat to U.S. Agriculture. P. Roy. Entomol. Soc. Wash. 2002; 104(4): 825-836.

[31] Pieterse W, Muller DL, Vuuren BJv. A molecular identification approach for five species of mealybug (Hemiptera: Pseudococcidae) on citrus fruit exported from South Africa. Afr. Entomol. 2010; 18(1): 23-28.

[32] Ben-Dov Y, Hodgson CJ. Soft scale insects; their biology, natural enemies and control. World Crop Pests, 7A. Sabelis MW, editor. Amsterdam: Elsevier; 1997. $425 \mathrm{p}$.

[33] Hagen LS, Jacquemond M, Lepingle A, Lot H, Tepfer M. Nucleotide sequence and genomic organization of cacao swollen shoot virus. Virology. 1993; 196(2): 619-628. PubMed PMID: 7690503.

[34] Gray SM, Banerjee N. Mechanisms of arthropod transmission of plant and animal viruses. Microbiol. Mol. Biol. R. 1999; 63(1):128-148. PubMed PMID: 10066833. Pubmed Central PMCID: 98959.

[35] Entwistle PF, Longworth JF. The relationships between cacao viruses and their vectors: the feeding behaviour of three mealybug (Homoptera: Pseudococcidae) species. Ann. Appl. Biol. 1963; 52(3): 387-391.

[36] Bigger M. The relative abundance of the mealybug vectors (Hemiptera: Coccidae and Pseudococcidae) of Cacao swollen shoot disease in Ghana. B. Entomol. Res. 1981;71(03):435.

[37] Sutherland JRG, editor Some observations on mealybugs infesting cacao in Western Region, Nigeria, 1950-1953. West African International Cacao Research Conference; 195312 - 16 December; West African Cacao Research Institute, Tafo, Gold Coast: Crown Agents for Oversea Governments and Administrations, Millbank, London.

[38] Strickland AH. The entomology of swollen shoot of cacao I.- the insect species involved, with notes on their biology. B. Entomol. Res. 1951;41(04):725.

[39] Gatehouse LN, Sutherland P, Forgie SA, Kaji R, Christeller JT. Molecular and histological characterization of primary (Betaproteobacteria) and secondary (Gammaproteobacteria) endosymbionts of three mealybug species. Appl. Environ. Microb. 2012; 78(4): 1187-1197. PubMed PMID: 22156418. Pubmed Central PMCID: 3273002.

[40] Lopez-Madrigal S, Latorre A, Porcar M, Moya A, Gil R. Complete genome sequence of "Candidatus Tremblaya princeps" strain PCVAL, an intriguing translational machine below the living-cell status. J. Bacteriol. 2011; 193(19): 5587-5588. PubMed PMID: 21914892. Pubmed Central PMCID: 3187454.

[41] Thao ML, Gullan PJ, Baumann P. Secondary (-Proteobacteria) endosymbionts infect the primary (-Proteobacteria) endosymbionts of mealybugs multiple times and coevolve with their hosts. Appl. Environ. Microb. 2002; 68(7): 3190-3197.

[42] von Dohlen CD, Kohler S, Alsop ST, McManus WR. Mealybug beta-proteobacterial endosymbionts contain gamma-proteobacterial symbionts. Nature. 2001; 412(6845): 433-436. PubMed PMID: 11473316.

[43] Tsai CW, Rowhani A, Golino DA, Daane KM, Almeida RP. Mealybug transmission of Grapevine leafroll viruses: an analysis of virus-vector specificity. Phytopathology. 2010; 100(8): 830-834. PubMed PMID: 20626287.

[44] Pseudococcus viburni (PSECOB). European and Mediterranean Plant Protection Organization (EPPO) Global Database (available online), accessed on 8 November 2015. https://gd.eppo.int [Internet]. 2015.

[45] Jara V, Meza FJ, Zaviezo T, Chorbadjian R. Climate change impacts on invasive potential of pink hibiscus mealybug, Maconellicoccus hirsutus (Green), in Chile. Climatic Change. 2012; 117(1-2): 305-317.

[46] Parsa S, Kondo T, Winotai A. The cassava mealybug (Phenacoccus manihoti) in Asia: first records, potential distribution, and an identification key. PLoS One. 2012; 7(10): e47675. PubMed PMID: 23077659. Pubmed Central PMCID: 3471874.

[47] Fand BB, Tonnang HEZ, Kumar M, Bal SK, Singh NP, Rao DVKN, et al. Predicting the impact of climate change on regional and seasonal abundance of the mealybug Phenacoccus solenopsis Tinsley (Hemiptera: Pseudococcidae) using temperature-driven phenology model linked to GIS. Ecol. Model. 2014; 288: 6278.

[48] Franco JC, Zada A, Mendel Z. Novel Approaches for the Management of Mealybug Pests. 2009: 233-278. 


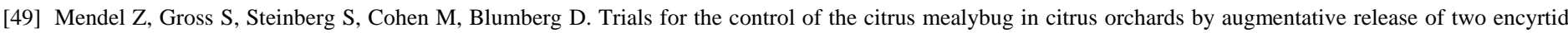
parasitoids. Entomol., Bari. 1999; 33: 251-265.

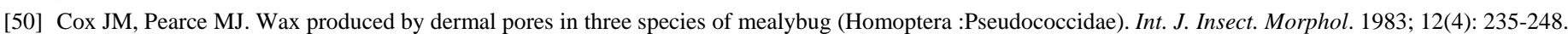

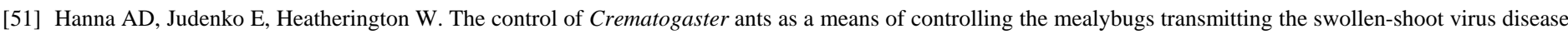
of cacao in the Gold Coast. B. Entomol. Res. 1956; 47(2): 219-226.

\section{AUTHORS}

First Author - Ekemini Obok , School of Agriculture, Policy and Development, University of Reading, RG6 6AR Reading, United Kingdom.

Second Author - Andy Wetten, School of Agriculture, Policy and Development, University of Reading, RG6 6AR Reading, United Kingdom.

Third Author - Joël Allainguillaume, University of the West of England, Frenchay Campus, Coldharbour Lane, Bristol, BS16 1QY, United Kingdom

Correspondence Author - Ekemini Obok, Department of Crop Science, Faculty of Agriculture, Forestry and Wildlife Resources Management, University of Calabar, Calabar, Nigeria. Email: e.e.obok@unical.edu.ng; Tel.: +234-813-330-4788 